\title{
Differences in the Students' Perceptions on the Teaching of Neuroanatomy in a Medical Curriculum Organized by Disciplines and an Integrated Medical Curriculum
}

\section{Diferenças na Perceção dos Estudantes Sobre o Ensino da Neuroanatomia num Currículo Médico Organizado por Disciplinas e num Currículo Médico Integrado}

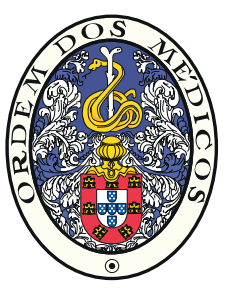

\author{
Mavilde ARANTES $\square^{1}$, Joselina BARBOSA ${ }^{2}$, Maria Amélia FERREIRA ${ }^{2}$
}

Acta Med Port 2017 Jan;30(1):26-33 - http://dx.doi.org/10.20344/amp.7307

\section{ABSTRACT}

Introduction: On the subject of curriculum reform, most European medical schools are moving away from an educational approach consisting of discipline-based courses to an integrated curriculum. The aim of this study was to compare, in the Faculty of Medicine of the University of Porto, Portugal, the teaching of neuroanatomy in a medical curriculum organized by disciplines and in an integrated medical curriculum.

Material and Methods: Two hundred sixty one students who completed the Curricular Unit with a discipline-based approach (Neuroanatomy) and 202 students who completed it with an integrated approach (Morphophysiology of the Nervous System) were asked to complete a questionnaire on their perceptions about the Curricular Unit.

Results: Our study showed that students of the Curricular Unit with a discipline-based approach had higher grades and evaluated it higher than students who followed the integrated approach. However, it also showed that students' grades had a significant effect on the evaluation of the curricular unit, with students with higher grades evaluating higher than students with lower grades. Besides, the majority of the students of the Curricular Unit with an integrated approach appreciated this curriculum model and highlighted as a positive point the successful integration of contents covered in the three components of the curricular unit.

Discussion: The curriculum reform led to the integration of neuroanatomy with other disciplines and resulted in a reduction of the teaching hours, a redefinition of the syllabus contents and the students' learning objectives, the introduction of new educational methods and changes in the evaluation system.

Conclusion: Our study could not prove conclusively the supremacy of one pedagogic approach to neuroanatomy over the other. Future initiatives to explore different pedagogical models in medical education are needed and should be of major concern to the medical faculty.

Keywords: Curriculum; Educational Measurement; Education, Medical, Undergraduate; Neuroanatomy/education; Students, Medical, Portugal

\section{RESUMO}

Introdução: No contexto da reforma curricular, a maioria das escolas médicas europeias estão a transitar de uma abordagem educacional consistindo em cursos 'baseados em disciplinas' para um currículo integrado. O objetivo deste estudo foi comparar, na Faculdade de Medicina da Universidade do Porto, Portugal, o ensino de neuroanatomia num currículo médico organizado por disciplinas e num currículo médico integrado.

Material e Métodos: Duzentos e sessenta e um estudantes que completaram a Unidade Curricular com uma abordagem 'baseada em disciplinas' (Neuroanatomia) e 202 estudantes que completaram a unidade curricular com uma abordagem integrada (Morfofisiologia do Sistema Nervoso) preencheram um questionário sobre as suas percepções acerca da Unidade Curricular.

Resultados: O nosso estudo mostrou que os estudantes da unidade curricular com uma abordagem 'baseada em disciplinas' tiveram classificações mais elevadas e avaliaram melhor a unidade curricular que os estudantes da unidade curricular com uma abordagem integrada. No entanto, também revelou que as classificações dos estudantes tiveram um efeito significativo na avaliação da unidade curricular, tendo constatado que os estudantes com classificações mais elevadas avaliaram melhor que os estudantes com classificações mais baixas. De referir ainda que a maioria dos estudantes da unidade curricular com uma abordagem integrada apreciou este modelo de ensino e destacou como um ponto positivo a integração bem-sucedida dos conteúdos abordados nos três componentes da unidade curricular.

Discussão: A reforma curricular conduziu à integração da neuroanatomia com outras disciplinas, associada a uma redução das horas de ensino, a uma redefinição do conteúdo programático e dos objetivos de aprendizagem dos alunos, introdução de novos métodos educacionais e mudança no sistema de avaliação.

Conclusão: O nosso estudo não provou conclusivamente a supremacia de uma abordagem de ensino de neuroanatomia em detrimento de outra. Futuras iniciativas para explorar diferentes modelos pedagógicos em educação médica são necessárias e devem ser de grande preocupação para a comunidade académica.

Palavras-chave: Avaliação Educacional; Currículo; Educação Médica Pré-Graduada; Estudantes de Medicina; Neuroanatomia/ ensino; Portugal

\footnotetext{
1. Department of Anatomy. Faculty of Medicine. University of Porto. Porto. Portugal.

2. Department of Medical Education and Simulation. Faculty of Medicine. University of Porto. Porto. Portugal.

$\square$ Autor correspondente: Mavilde Arantes. mavildearantes@hotmail.com

Recebido: 13 de dezembro de 2015 - Aceite: 05 de julho de 2016 | Copyright @ Ordem dos Médicos 2017
} 


\section{INTRODUCTION}

Human anatomy, which includes gross and neuroanatomy, has always represented a crucial basic science in medical schools, ${ }^{1}$ providing a platform of knowledge suitable to all medical careers. Neuroanatomy, in particular, is a fundamental cornerstone to clinical neurosciences, and this subject is included in every North American and European medical curricula. ${ }^{2}$

However, in the last decades, due to an explosion of knowledge in biomedical sciences and advances in medical research and technology, ${ }^{3}$ medical education has been in a state of change and medical educators are challenged to reform the medical curriculum. ${ }^{4}$ In response to these new medical issues, and following the evidence from the fields of education and psychology, dramatic changes have been made in medical education to ensure that students have the basic knowledge and skills necessary for future practice. ${ }^{5}$ One of the major pedagogical changes has been the movement towards a competency-based educational curriculum, with outcome-based objectives and studentcentred approaches. In addition, teaching strategies that promote active learning and problem solving are increasingly being advocated. ${ }^{6}$

In Europe, the Bologna Process had a profound influence in the curricular reform of undergraduate medical programs, providing guidelines to ensure more comparable, compatible and coherent models, ${ }^{7-9}$ under the creation of an 'European Higher Education Area' (EHEA). In this context, most European medical schools are moving away from an educational program consisting of discipline-based courses formats of more or less integrated curricula. ${ }^{10}$ In Portugal, after a period of contestation and even denial of the adequacy of the Bologna Process to medical courses, related mainly to the specificities of medical education, the Portuguese Universities have made efforts to substantiate the EHEA. In 2005, a joint project of the Portuguese Medical Schools produced a document where it is stated that 'The purpose of pre-graduate medical education is to help the medical student to acquire a solid and coherent knowledge base, together with an appropriate set of values, attitudes and skills (...)'. ${ }^{11}$ In this context, in 2007, the Faculty of Medicine of Porto University (FMUP) formally accepted the adequacy of Bologna's pedagogical framework, namely by adopting for its undergraduate medical studies the format of a Cycle of Integrated Master Studies in Medicine.

Within this new paradigm in undergraduate medical education, ${ }^{12,13}$ the teaching of neuroanatomy is also facing changing times. Until 2013/2014, neuroanatomy was taught in FMUP as a stand-alone second-year discipline. Since then the teaching of neuroanatomy was integrated with neurophysiology and neurohistology as a first-year curricular unit (CU) called Morphophysiology of the Nervous System, preceded by the CU of Morphophysiology of the Locomotor System. The present study aimed to compare the two different pedagogical approaches (discipline-based versus integrated) by analysing the perceptions of the medical students who attended classes following these two pedagogical approaches.

\section{MATERIAL AND METHODS \\ Description of the CUs}

Neuroanatomy, as a discipline-based CU, was lecture-based and faculty-centred, with little integration across courses. In fact, this traditional format focuses on neuroanatomy in a passive learning paradigm. There were 30 hours of lectures and 45 hours of practices and laboratory classes allotted to the teaching of the $\mathrm{CU}$. Each lecture lasted one hour (two lectures per week) and each practice and laboratory class consisted in analysis of prosections of the brain and spinal cord (three hours per week). The major component topics of the $\mathrm{CU}$ included spinal cord, brain stem, cerebellum, thalamus, epithalamus, hypothalamus, hypophysis, subthalamus and basal ganglia, telencephalon, limbic system, afferent and efferent pathways, autonomic nervous system, cerebral vessels, ventricular system, meninges, cranial nerves, and mechanisms of vision and hearing. The assessment of this $\mathrm{CU}$ consisted of a distributed evaluation (corresponding to $40 \%$ of the grade) plus a final evaluation (corresponding to $60 \%$ of the grade), both with a practical test of identification of neuroanatomical structures and a written theoretical test with short-answer questions.

In Morphophysiology of the Nervous System, neuroanatomy is taught alongside with neurophysiology and neurohistology. In this system-based approach, the programme of neuroanatomy includes bones of the skull and face, temporomandibular joint, hyoid bone, muscles of mastication and mimic, neck muscles, spinal cord, autonomic nervous system, spinal peripheral nerves, brain stem, cerebellum, thalamus, epithalamus, hypothalamus, hypophysis, subthalamus and basal ganglia, telencephalon, ventricular system, meninges, limbic system, afferent and efferent pathways, cranial nerves, and mechanisms of vision and hearing. It consists on formal lectures of relevant concepts and anatomical organization (a total of four lectures, one hour each one, across the module) and theoretical-practice classes focused on gross morphology, main internal structures, function, medical imaging, and clinical importance of each area of the nervous system ( \pm 60 hours). Based on an understanding of normal neural connections and nervous system function, the anatomical basis of various neurological disorders is also explored. Theoretical-practical classes also include computed tomography (CT) and magnetic resonance imaging (MRI) scans, prosections, cross-sectional material (including specimens, particularly brain tissues) and anatomical models as learning resources. The teacher's role is to highlight the most important information in a functionally relevant construct. Summaries outlining the level of anatomical knowledge that students are expected to learn in each theoretical-practice classes are provided to indicate the core knowledge required; the integration with neurophysiology and neurohistology is included. The 
assessment of this CU consists of a final examination, with a practical component of identification of the neuroanatomical structures and a written theoretical component with shortanswer questions.

\section{Data collection}

All second-year medical students who have completed the Neuroanatomy (Neuro) $\mathrm{CU}$ and all first-year medical students who have completed the Morphophysiology of the Nervous System (Morpho) CU were invited to complete a structured and anonymous questionnaire (included as Appendix 1) [http://www.actamedicaportuguesa.com/ revista/index.php/amp/article/view/7307/4883], consisting of three parts. The first part was about the socio-demographic factors of the participants, including age and gender, and the classification obtained in the assessment procedures of the $\mathrm{CU}$. The second part, comprising 20 questions, evaluated the participant's perceptions about the CU (e.g., 'The CU was well organized'). Participants answered these questions using a 5-point Likert scale (1 being 'strongly disagree', and 5 being 'completely agree'). The last part integrated three short-open questions asking participants to indicate the most positive and the most negative aspects of the $\mathrm{CU}$ and to offer comments and suggestions on how to improve the $\mathrm{CU}$. An additional question provided participants with the opportunity to offer their overall appreciation of the $\mathrm{CU}$ on a Likert scale from 1 to 5 ( 1 being 'very dissatisfied' and 5 being 'very satisfied').

\section{Data analysis}

Descriptive analyses were applied to determine the baseline characteristics of our study population. Proportion comparisons were made using the Chi-square test and the Mann-Whitney test was used for the comparison of continuous variables.

The psychometric quality of the questionnaire was measured by factor analysis and reliability. The factor analysis included an exploratory factor analysis (EFA) and a confirmatory factor analysis (CFA). Because the results of EFA may not be replicable in a new sample ${ }^{14}$ the total sample $(n=463)$ was large enough to be randomly divided into two samples of approximately equal size. ${ }^{15}$ The first sample $(n=229$ ) was used to perform EFA using Principal Components with oblique rotation. Prior to this, the compliance with the criteria of Bartlett's sphericity test was verified as well as the KMO index (Kaiser-Meyer-Olkin). The scree plot and the Kaiser Criterion (eigenvalue 1.0) were used to identify the most interpretable solution. It was considered that items with absolute factor loadings of 0.35 or greater are interpreted as having a meaningful part on the whole factor. Once the factor structure was established using EFA, this factorial structure was verified by CFA in the second sample $(n=234)$. The model's goodness-of-fit was evaluated based on the following criteria ${ }^{16}$ : the Chi-squared divided by the degrees of freedom (good fit $<3.0$ ), Bentler's Comparative Fit Index (CFI; good fit >0.9), the Tucker-Lewis Index (TLI; good fit > 0.9) and the Root Mean Square Error of Approximation (RMSEA; good fit < 0.06). Model fitting to the theoretical considerations went beyond the modification indices. The reliability was tested by assessing the internal consistencies with the Cronbach's alpha. A Cronbach's alpha of 0.7 or higher was considered. ${ }^{17}$

To assess the effect of grade levels and $\mathrm{CU}$ on the change in each factor, we used the general linear model with adjustment for age groups and gender. The differences between groups in factors scores were tested by using bootstrap techniques due to the skewed distribution. In order to assess whether the students' perceptions differed in the studied CUs, association between $\mathrm{CU}$ and questionnaire factors scores were estimated using generalized linear models, adjusting for age groups, grades and gender.

All statistical analyses were performed using the Statistical Package for Social Sciences (SPSS) version 22.0. The $p$ value was set at 0.05 .

Note that one of the authors (J.B.) has a degree in mathematics and expertise in statistics.

\section{RESULTS \\ Participants' characteristics}

Comparisons between the two split-half subsamples regarding demographic variables are shown in Table 1. There were no statistical differences between the two split-half samples on a variety of characteristics including gender, age, grade and CU. These results suggest that the random split was successful thus allowing two independent samples to be analyzed.

\section{Validity and reliability of the questionnaire}

The first sample was used to construct a model and the second sample was used to validate the model and to control for possible over fitting of the data.

\section{Exploratory analysis}

The main component analysis resulted in a three-factor structure explaining $61.70 \%$ of the total variance. Factor 1 showed higher reliability when deleting the item 15 'time available for the exam was adequate' and this was excluded from the analysis. The exploratory factor analysis of the 19 items in the questionnaire produced factor loadings from 0.350 to 0.941 and item communality values from 0.504 to 0.728 (Table 2).

Based upon examination of the items and the prior theoretical evidence, Factors 1,2 and 3 were labelled as students' evaluation of the CU (Factor 1), the time dedicated to the $\mathrm{CU}$ (Factor 2) and relevance of the $\mathrm{CU}$ for training to become a doctor (Factor 3) (Table 2).

\section{Confirmatory analysis}

CFA was used to test the results from the EFA in the other half of the randomly split sample. The 3 factor solution and 19 observed variables tested by CFA showed poor fit. After reading the modification indices, two items were excluded (number 2, the program presented stimulated learning and number 20 , the $\mathrm{CU}$ lived up to my expectations) for 
Table 1 - Demographic characteristics of the sub-samples

\begin{tabular}{|c|c|c|c|c|}
\hline Characteristic & $\begin{array}{c}\text { Total sample } \\
(n=463)\end{array}$ & $\begin{array}{l}\text { Half-sample } 1 \\
\quad(n=229)\end{array}$ & $\begin{array}{l}\text { Half-sample } 2 \\
\quad(n=234)\end{array}$ & $p$-value \\
\hline Age* $^{*}$ & $19(19-20)$ & $19(19-20)$ & $19(19-20)$ & 0.058 \\
\hline \multicolumn{5}{|c|}{ Age groups, n (\%) } \\
\hline 18 to 19 & $282(60.9)$ & $153(65.4)$ & $129(56.3)$ & 0.133 \\
\hline 19 & $109(23.5)$ & $48(20.5)$ & $61(26.6)$ & \\
\hline$\geq 20$ & $72(15.6)$ & $33(14.1)$ & $39(17.0)$ & \\
\hline \multicolumn{5}{|l|}{ Gender, n (\%) } \\
\hline Female & $296(63.9)$ & $156(66.7)$ & $140(61.1)$ & 0.215 \\
\hline Male & $167(36.1)$ & $78(33.3)$ & 89 (38.9) & \\
\hline Grade $^{*}$ & $14(12-16)$ & $14(11-16)$ & $14(12-16)$ & 0.832 \\
\hline \multicolumn{5}{|c|}{ Curricular unit, n (\%) } \\
\hline Morpho & $202(43.6)$ & $107(45.7)$ & $95(41.5)$ & 0.357 \\
\hline Neuro & $261(56.4)$ & $127(54.3)$ & $134(58.5)$ & \\
\hline
\end{tabular}

${ }^{*}$ Median (p25 - p75)

The CFA indicated that the 3-factor model suggested by the EFA produced an acceptable $t$ based on recommended standards.

Table 2 - Exploratory factor analysis (EFA) with oblique rotation of the scale

\begin{tabular}{llcccc}
\hline Domains & \multicolumn{1}{c}{ Items } & \% Variance explained & Eigenvalues & $\boldsymbol{h}^{2}$ (range) & Factor loadings (range) \\
\hline Students' evaluation & $\begin{array}{l}1,2,3,4,5,9,10, \\
11,1213,14,16\end{array}$ & 49.1 & 9.336 & $0.501-0.742$ & $0.350-0.941$ \\
& $\begin{array}{l}1,7,8 \\
\text { Dedicated time }\end{array}$ & 7.1 & 1.344 & $0.634-0.717$ & $0.616-0.797$ \\
Relevance for training & $17,18,19,20$ & 5.5 & 1.044 & $0.652-0.710$ & $0.677-0.909$ \\
\hline
\end{tabular}

$h^{2}$ : Communalities

Table 3 - Effect of CU and grades in factor scores

\begin{tabular}{|c|c|c|c|c|c|c|}
\hline & \multicolumn{2}{|c|}{ Students' evaluation* } & \multicolumn{2}{|c|}{ Dedicated time* } & \multicolumn{2}{|c|}{ Relevance for training* } \\
\hline & $\beta$ coef. $(95 \% \mathrm{Cl})$ & $p$-value & $\beta$ coef. $95 \% \mathrm{Cl}$ & $p$-value & $\beta$ coef. $95 \% \mathrm{Cl}$ & $p$-value \\
\hline \multicolumn{7}{|l|}{$\mathrm{CU}$} \\
\hline Morfo & 1 & & 1 & & 1 & \\
\hline Neuro & $12.2(8.6 ; 15.5)$ & 0.001 & $22.9(18.1 ; 27.6)$ & $<0.001$ & $5.2(0.5 ; 9.8)$ & 0.029 \\
\hline Grades & $0.9(0.4 ; 1.5)$ & 0.002 & $1.8(1.0 ; 2.6)$ & $<0.001$ & $2.0(1.3 ; 2.6)$ & 0.001 \\
\hline
\end{tabular}

*Adjusted for gender and age groups

saturating in more than one factor and a high correlation was identified between the error terms of items 11 ("') and 12 ("'). A new refined model was devised and goodness of fit was obtained: (a) Chi-square divided by the degrees of freedom was 1.78; (b) the CFI was 0.957 ; (c) the TLI was 0.949; (d) and the RMSEA was 0.058 .

\section{Internal consistency of the scale}

The Cronbach reliability of the items for each subscale in all samples was 0.903 for Students' Evaluation (Factor 1), 0.842 for Dedicated Time (Factor 2) and 0.837 for Relevance for Training (Factor 3). The Cronbach's alpha for the entire survey was 0.931 .

\section{Students' evaluation}

In order to determine whether students' grade levels and CU were associated with each factor, a multivariate analysis was performed. The results revealed significant main effects for CU and grade level in all Factors (Table 3). There were effects of grade (students with higher grades evaluate higher than students with lower grades) and $\mathrm{CU}$ (Morpho versus Neuro, with Neuro students evaluating higher than 'Morpho' students). Fig. 1 presents CU patterns of responses on each factor.

\section{Points considered most positive in the Neuro versus Morpho CU}

Regarding the Neuro CU, the students' responses were coded and organized according to their content (Table 4).

The majority (95\%) of the participants mentioned, as one of the most positive points, the well-defined structure of the whole CU. The level of content was mentioned by $87 \%$ of the students. The presentation style and the quality of the teachers were pointed out by $80 \%$ of the students.

Within the Neuro CU universe of 261 students, $90 \%$ mentioned, as one of the most negative points, the excessive detail in some subject matters taking into account the small number of hours allocated to the CU. The scarcity of clinical references in classes was reported by $60 \%$ of the students. 


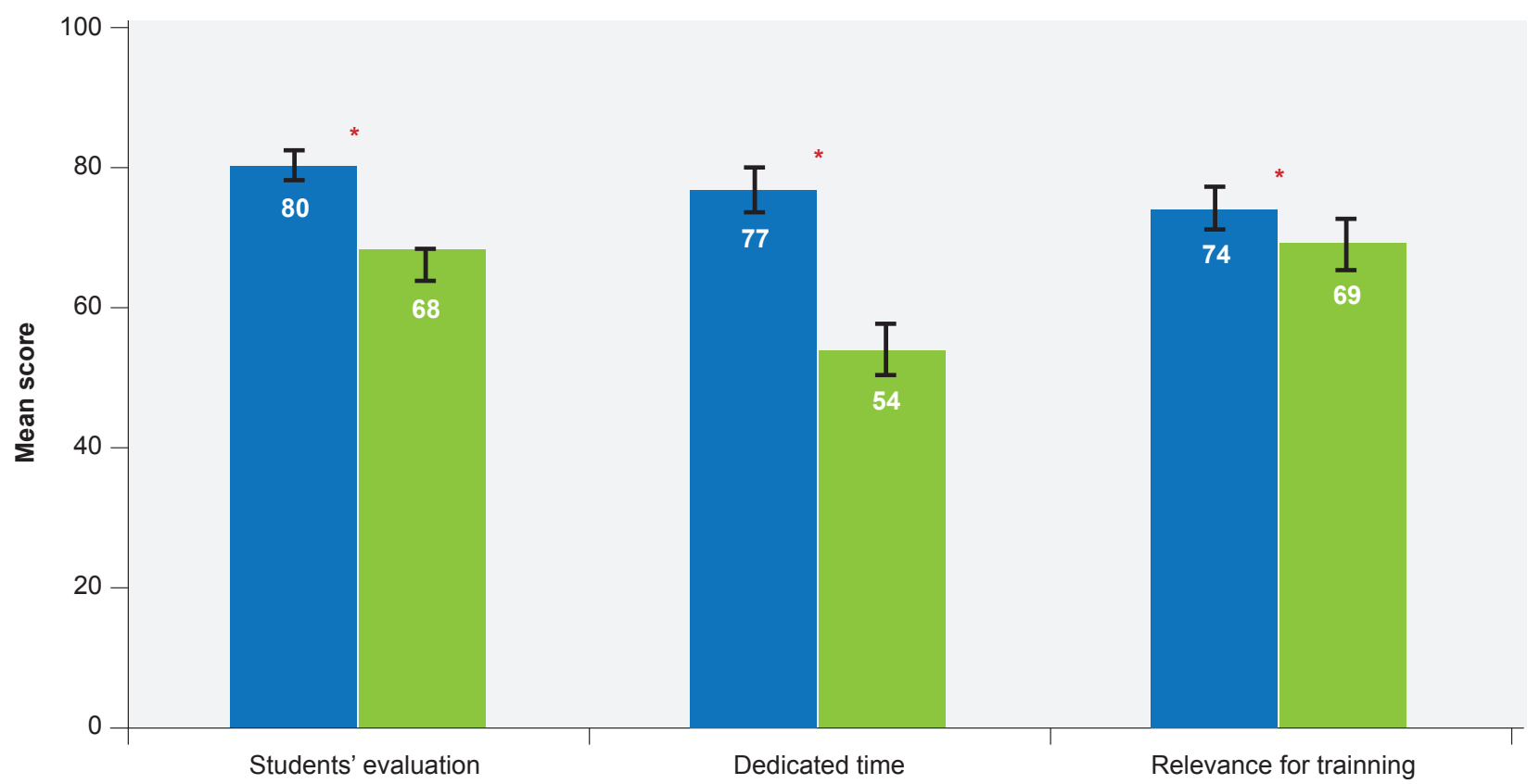

"Neuro"

"Morpho"

Figure 1 - Estimated means for factors' scores by CU. Means adjusted values for gender, age groups and grades. Bars represent: $95 \%$ confidence interval. The * indicates significant $(p<0.05)$ differences between CU.

Regarding the comments and suggestions on the Neuro CU, $70 \%$ suggested greater clinical correlation, with the presentation of clinical cases/pathologies related to the subject matters studied; $60 \%$ suggested providing lists with the core curriculum and $54 \%$ suggested the need to give more emphasis to the really important aspects. The overall appreciation of the CU was very good. Most of the participants $(n=134 ; 51 \%)$ rated the $\mathrm{CU}$ as 'very useful', $106(41 \%)$ rated it as 'extremely useful' and $16(6 \%)$ rated the $\mathrm{CU}$ as 'useful' (Table 4).

Regarding the Morpho CU (Table 5), the majority $(95 \%)$ of the participants mentioned, as one of the most positive points, the high quality of the handouts, summaries and PowerPoint slides; 90\% mentioned the well-defined structure of the whole $\mathrm{CU} ; 85 \%$ mentioned the high quality of the teachers and $80 \%$ made reference to the presentation style. The successful integration of contents covered in the three components of the $\mathrm{CU}$ was pointed out by $82 \%$ of the students, whereas $77 \%$ referred the level of content and $68 \%$ mentioned that the evaluation was fair.

Within the Morpho CU 202 students who answered the questionnaire, $90 \%$ mentioned, as one of the most negative points, the huge amount of subject contents for the number of hours allocated to the $\mathrm{CU}$, and $86 \%$ pointed out the very extensive curriculum, covering not only the central nervous system and cranial nerves but also the spinal nerves, bones and muscles of the head and neck; $60 \%$ cited the fact that there are few lectures.

Regarding the comments and suggestions on the CU, $70 \%$ suggested the need to include more neuroanatomy classes, $70 \%$ the need for more lectures and $70 \%$ the need to review the syllabus, with reduction or elimination of some

Table 4 - Points considered most positive in the Neuro CU grouped into themes

\begin{tabular}{lcl}
\hline Positive points & $\mathbf{n}(\%)$ & Descriptions \\
\hline CU organization & $248(95 \%)$ & Good organization of the unit \\
Level of content & $227(87 \%)$ & $\begin{array}{l}\text { Well-structured lessons } \\
\text { Clarity of objectives proposed and information displayed } \\
\text { Applicability of the contents taught }\end{array}$ \\
& $208(80 \%)$ & $\begin{array}{l}\text { Classes were extremely well taught, transmitting knowledge appropriately } \\
\text { How knowledge was transmitted }\end{array}$ \\
Presentation style & How issues were presented, with emphasis on the most relevant points to our clinical practice \\
& $208(80 \%)$ & $\begin{array}{l}\text { Great work environment and motivation of the teachers } \\
\text { Teachers were engaged in teaching and supported us } \\
\text { Quality of the teachers }\end{array}$ \\
& & Availability of teachers to answer questions
\end{tabular}


Table 5 - Points considered most positive in the Morpho CU grouped into themes

\begin{tabular}{|c|c|c|}
\hline Positive points & n (\%) & Descriptions \\
\hline \multirow{3}{*}{ CU organization } & \multirow{3}{*}{$182(90 \%)$} & Well-defined program \\
\hline & & Compliance with the program agreed \\
\hline & & Existence of several experimental 'practical tests' \\
\hline \multirow[t]{3}{*}{ Integration of the content } & \multirow[t]{3}{*}{$165(82 \%)$} & $\begin{array}{l}\text { Successful integration of contents covered in the three components of the CU } \\
\text { (neurohistology, neurophysiology and neuroanatomy) }\end{array}$ \\
\hline & & $\begin{array}{l}\text { Good integration of neuroanatomy with the other components (neurophysiology and } \\
\text { histology) }\end{array}$ \\
\hline & & Good coordination between the co-conductors \\
\hline \multirow{3}{*}{ Level of content } & \multirow{3}{*}{$155(77 \%)$} & Correlation of anatomical content with clinical practice \\
\hline & & Several concepts learned have practical applicability \\
\hline & & Matters were explained more than once, integrating them in new contexts \\
\hline \multirow{3}{*}{ Presentation style } & \multirow{3}{*}{$161(80 \%)$} & Classes were extremely well taught, transmitting knowledge appropriately \\
\hline & & How knowledge was transmitted \\
\hline & & How issues were presented, with emphasis on the most relevant points to our clinical practice \\
\hline \multirow{4}{*}{ Quality of the teachers } & \multirow{4}{*}{$171(85 \%)$} & Competence of the teaching staff \\
\hline & & Remarkable effort made by teachers of $\mathrm{CU}$ \\
\hline & & Teachers were available to answer questions \\
\hline & & Teachers were engaged in teaching and supported students \\
\hline \multirow{4}{*}{$\begin{array}{l}\text { Handout/summaries/ } \\
\text { power-point quality }\end{array}$} & \multirow{4}{*}{$192(95 \%)$} & Support material provided was of high quality \\
\hline & & Very good PowerPoints \\
\hline & & Summaries of theoretical-practical classes organized and complete \\
\hline & & Summaries of lessons were very clear and were of a great support to study \\
\hline Evaluation & $137(68 \%)$ & Assessment was consistent with what was taught \\
\hline
\end{tabular}

subject matters.

The overall appreciation of the CU was good. Most of the participants $(n=84 ; 41 \%)$ rated the CU as 'very useful', $67(33 \%)$ rated the CU as 'useful', and $10(5 \%)$ rated it as 'extremely useful'.

\section{DISCUSSION}

Our results demonstrated that students from the discipline-based approach (Neuro) obtained higher grades and evaluated higher than students from the integrated approach (Morpho). However, our study also showed that students' grades had a significant effect in the CU evaluation, with students with higher grades evaluating it higher than students with lower grades. Furthermore although the $\mathrm{CU}$ has always an effect, this effect is lower in factor 3 (Relevance for Training), increasing the effect of the grade. Besides, the majority of the Morpho students appreciated the integrated approach and pointed out as positive the successful integration of contents covered in the three components of the CU.

Our results showed that it is very difficult to objectively evaluate which pedagogical approach is better when teaching neuroanatomy. From an educational point of view, it is understandable that the implementation of a curriculum change can be hard, which may explain the lower grades obtained by the Morpho students. It is a difficult time for students (who can no longer use previous years notes), but especially for teachers, who have to adapt themselves to a new CU, with a new program, new teaching methodologies and new assessment systems. ${ }^{18}$ In addition, neuroanatomy is now taught in the first-year of the medical course, which can also contribute to the lower scores, since students are still quite young/immature to deal with the complexity of the topic, have a limited knowledge of the human body in general, are still developing a study methodology adequate for higher education and are dealing with the emotional and practical challenges associated with college life. ${ }^{19}$ In the first years of the course, a discipline-based approach can constitute, to the students, an easier way to deal with the subject, as the content is more focused on the discipline.

With regard to other basic sciences there are, in the literature, some articles comparing the two educational models in what concerns student knowledge, with different results. While the introduction of a new system-based course in anatomy was reported by some authors as having a negative impact on the medical students' knowledge, ${ }^{20}$ others have found that an integrated curriculum for the first year of medical school for morphology, biochemistry, physiology, and neurobiology, resulted in higher or equivalent subject examination scores. ${ }^{21}$

Our study showed that the implementation of a new curriculum is a difficult task, and that the changes that are being made in education in general and in the teaching of neuroanatomy, in particular, should be critically evaluated 
and fully debated within the medical community. Although Bologna provided us with some guidelines, how to design the best neuroanatomy course is a question with no standard answer and one that is affected by the resources available in different medical schools.

This work also provides an important contribution to the discussion around the two models of medical curriculum (discipline-based versus integrated). Our results showed that both models have positive and negative aspects. Regarding the integrated approach the students have mentioned, as one of its most positive points, the successful integration of contents covered in the three components of $\mathrm{CU}$ and, as negative points, the huge amount of subject contents for the number of hours allocated to the $\mathrm{CU}$, the very extensive curriculum and the fact that there are few lectures.

In the literature, interdisciplinary teaching has been shown to increase interest in basic science subjects. ${ }^{22,23}$ Integration of instruction in neuroanatomy with other disciplines facilitates the establishment of a link between neuroanatomyand othermedicalareasand the understanding of the anatomical reasons behind clinical skills. ${ }^{24-26}$ Furthermore, integration reduces unnecessary redundancy between courses and provides less compartmentalized teaching and testing. However, it is not always easy to promote content integration. Total collaboration between the co-conductors of the different disciplines is necessary to promote a balanced morphophysiologic education even in cases where each co-conductor wants his/her course to have the largest number of classes possible. It is also noted that, in this new curricular approach, fewer highly specialized neuroscience experts are necessary, as they are replaced by educators capable of orchestrating a more diverse learning experience.

In FMUP, the integration of neuroanatomy with other disciplines, combined with a reduction of teaching hours, made it impossible to continue to deliver the complex details that were delivered in the traditional neuroanatomy program, most of them inadequate to basic undergraduate medical education. Under such constraints, our neuroanatomy curriculum was redefined to focus more heavily on the most clinically relevant topics. Johnson et $a^{27}$ found that when clinicians highlighted the clinical relevance of material, the level of interest of the anatomy students increased substantially. Besides, nowadays, students demand evidence that what is being taught is truly necessary and clinically relevant. ${ }^{28}$ Excessive amount of apparently irrelevant material in a curriculum encourages superficial learning. In our study, most of the Neuro students (from the discipline-based approach) mentioned, as one of the most negative points, the excessive detail of some subject matters. Moxham et al, ${ }^{29}$ in their recent article, hugged this issue and designed a proposal of core syllabuses for the anatomical sciences, including neuroanatomy, keeping in mind the skills required for basic medical graduate studies. In order to teach the core neuroanatomical knowledge to medical students in the most efficient way for optimal knowledge acquisition, we also moved away from a teacher-centered approach towards a more student-centred approach. As a result of this, we reduced the number of traditional lectures, favouring theorical-practical classes with active student participation, mainly using case-based discussions. We also used active learning formats which will help medical students to develop life-long learning and problem-solving skills. A special emphasis was given on cross-sectional neuroanatomy and radiologic anatomy. Teaching anatomy to undergraduate medical students using imaging modalities, has been found to have many benefits, including improving performance. ${ }^{30}$

Testing and evaluating the neuroanatomical knowledge of the medical students was multimodal in both CU. However, in the Morpho $\mathrm{CU}$ there is no continuous assessment; evaluation takes place only at the end of the CU.

\section{Limitations and future directions}

We are aware that our study has some methodological limitations. First, the courses that were compared integrated students from two different years. Because students from the first and the second years are at different stages of training and are facing different challenges and experiences in the University environment, this may influence their perception and somehow condition their answers. Second, comparing a curricular approach that has been in place for several years (discipline-based) with a curricular approach that has only one year of existence (integrated), might also bias the results. Third, all participants were from the same institution, making it impossible to extrapolate the findings to medical students from different institutions.

Regarding future research, besides evaluating the students' perceptions, it would be interesting to compare in a further study the skills and knowledge acquired in the two different pedagogical approaches of neuroanatomy (discipline-based versus integrated).

Future studies should also investigate teachers' perceptions, not just students' perceptions. This would help determine if students' perceptions is influenced by their teachers' perceptions.

It could also be interesting to know if the present study could be replicated in other medical schools from Portugal or other countries. It would be advantageous to have other data that could be compared with the results of this study and, more specifically, it would be beneficial to determine if some of the results might have been affected by cultural factors.

\section{CONCLUSION}

Our study was the first to compare two different pedagogical approaches to teaching neuroanatomy (discipline-based versus integrated). Although, in Europe, the integrated approach is the most used in the new medical educational reality, both pedagogical approaches seem to have positive and negative aspects. In this work, we intended to provide a contribution to the debate on curriculum reform to ensure that undergraduate students 
are adequately educated in neuroanatomy. Future initiatives to explore different pedagogical models in medical education are needed and should be of major concern to medical faculty.

\section{PROTECTION OF HUMANS AND ANIMALS}

This study was approved by the Faculty of Medicine of the University of Porto/São João Hospital Ethics Committee in compliance with the Helsinki Declaration.

\section{REFERENCES}

1. Verhoeven $B H$, Verwijnen GM, Scherpbier AJ, Van Der Vleuten CP. Growth of medical knowledge. Med Educ. 2002;36:711-7.

2. Mateen F, D'Eon M. Neuroanatomy: a single institution study of knowledge loss. Med Teacher. 2008;30:537-9.

3. Elaine RM. A decade's perspective on DNA sequencing technology. Nature. 2011:470:198-203.

4. Sierles F. The revolution is upon us. Acad Medicine. 2010;85:799-805.

5. Leung K, Lu KS, Huang TS, Hsieh BS. Anatomy instruction in medical schools: connecting thep and the future. Adv Health Sci Educ. 2006;11:209-15.

6. Russell AT, Comello RJ, Wright DL. Teaching strategies promoting active learning in healthcare education. J Educ Health Dev. 2007;1.

7. Patrício $\mathrm{M}$, den Engelsen $\mathrm{C}$, Tseng $\mathrm{D}$, Ten CO. Implementation of the Bologna two-cycle system in medical education: Where do we stand in (2007)? - Results of an AMEE-MEDINE survey. Med Teacher. 2008;30:597-605.

8. Patrício M, Harden RM. Medical education and the Bologna process in EUA Bologna. Handbook: Making Bologna Work. Berlin: Raabe Academic Publishers and Brussels, European University Association; 2009. [accessed 2010 Jan 13]. Available from: http://www.bolognahandbook.com/.

9. Patrício M, Harden RM. The Bologna process - a global vision for the future of medical education. Med Teacher. 2010;32:305-15.

10. Drake RL. A unique, innovative, and clinically oriented approach to anatomy education. Acad Med. 2007,82,475-8.

11. O licenciado médico em Portugal. Lisboa: Faculdade de Medicina da Universidade de Lisboa; 2005.

12. Shaffer F. Teaching anatomy in the digital world. New Engl J Med. 2004;351:1279-81.

13. Drake RL, McBride JM, Lachman N, Pawlina W. Medical education in the anatomical sciences: the winds of change continue to blow. Anat Sci Educ. 2009;2:253-9.

14. Stuart $H$, Sartorius $N$, Liinamaa $T$. The images of psychiatry scale: development, factor structure, and reliability. BMC Psychiatry. 2014;14:337.

15. Marsh HW, Balla JR, McDonald RP. Goodness-of-fit indexes in confirmatory factor analysis. Psychological bulletin. 1988;103:391-410.

16. Hu LT, Bentler PM. Cutoff criteria for fit indexes in covariance structure analysis: Conventional criteria versus new alternatives. Struct Equ Modeling. 1999;6:1-55.

\section{DATA CONFIDENTIALITY}

The authors declare having followed the protocols in use at their working centre regarding patients' data publication.

\section{CONFLICTS OF INTEREST}

The authors declare that there are no conflicts of interest.

\section{FUNDING SOURCES}

No subsidies or grants contributed to this work.

17. Kehoe J. Basic item analysis for multiple-choice tests: ERIC clearinghouse on assessment and evaluation. 1995:398237. [accessed 2010 Jan 13]. Available from: http://ericae.net/digests/tm9511.htm.

18. Westwood P. Effective teaching. Aust Journal of Teacher Educ. 1996;21:66-84

19. Salvatore JE, Kendler KS, Dick DM. Romantic relationship status and alcohol use and problems across the first year of college. J Stud Alcohol Drugs. 2014;75:580-9.

20. McKeown PP, Heyling DJ, Stevenson M, McKelvey KJ, Nixon JR, McCluskey DR. The impact of curricular change on medical students knowledge of anatomy. Med Educ. 2003;37:954-61.

21. Klement BJ, Paulsen DF, Wineski LE. Anatomy as the backbone of an integrated first year medical curriculum: design and implementation. Anat Sci Educ. 2011;4:157-69.

22. Branch WT, Arky RA, Woo B, Stoeckle JD, Levy DB, Taylor WC. Teaching medicine as a human experience: a patient-doctor relationship course for faculty and first-year medical students. Annn Intern Med. 1991;114:482-9.

23. Montagna E, Moreno JA, Verde MJ, Maifrino LB. Posters as an instructional strategy for interdisciplinary teaching: an approach for applying anatomy to practical situations in a pharmacy course. J Morphological Sci. 2011;28,4:255-60.

24. Dangerfield $P$, Bradley $P$, Gibbs T. Learning gross anatomy in a clinical skills course. Clin Anat. 2000;13:444-7.

25. Stalburg CM, Stein TA. An interdisciplinary course in women's health integrating basic and clinical sciences: clinical anatomy and women's health. Am J Obstet Gynecol. 2002;187:S49-52.

26. Mclachlan JC, Bligh J, Bradley P, Searle J. Teaching anatomy without cadavers. Med Educ. 2004;38:418-24.

27. Johnson EO, Charchanti AV, Theodore GT. Modernization of an anatomy class: from conceptualization to implementation. A case for integrated multimodal-multidisciplinary teaching. Anat Sci Educ. 2012;5,354-66.

28. Older J. Anatomy: a must for teaching the next generation. Surgeon. 2004;2:79-90.

29. Moxham BJ, Plaisant OP, Smith CF, Pawlina W, McHanwell S. An approach toward the development of core syllabuses for the anatomical sciences. Anat Sci Educ. 2014;7:302-11

30. Erkonen WE, Albanese MA, Smith WL, Pantazis NJ. Effectiveness of teaching radiologic image interpretation in gross anatomy. A long-term follow-up. Invest Radiol. 1992;27:264-6. 